a variety of methods, X-ray work has yielded brilliant results. Dr. H. Lipson gave an example in direct conflict with the theory of phase equilibrium, that of the metal cobalt. The purity of the metal was 99.99 per cent, and yet it was not possible to find a definite transition point. On cooling, the hexagonal form begins to appear just above $300^{\circ} \mathrm{C}$. and the amount increases down to room temperature. On reheating, it only changes back to the face-centred cubic form above $400^{\circ} \mathrm{C}$.

Mr. G. D. Preston pointed out that X-rays can give additional information not available by the microscope. The mechanism of phase changes is most important. Dr. G. V. Rayner supported accurate work in order to supply reliable data to the theorists. He agreed that the X-ray method would often give results just as accurate as the microscopic, but it was no more speedy in operation.

Dr. W. Wrazej described the use of X-rays in the investigation of an iron alloy which showed two distinct groups of erystals on microscopic examination. The problem was whether these belonged to different phases or whether they were merely differently oriented crystals. The back-reflexion method proved that the latter was the true explanation.

Dr. A. H. Jay stated that he had just designed an $\mathrm{X}$-ray camera to work up to $1,500^{\circ} \mathrm{C}$. In determining phase boundaries by the lattice spacing method, difficulties were caused by irregularities as in the iron-nickel system. He expressed some scepticism about the value of extremely pure materials ; results do not always come up to expectations.

Dr. H. O'Neill, though very interested in phase diagrams, does not consider that extreme accuracy is of vital importance for industrial work. If alloys are examined in the lump form, the polished surface layer gives broadened lines. If this is removed by etching, there is a selective solution and the X-ray results are unreliable. Gas may upset the equilibrium of alloys. It would be interesting to follow the tempering process of steel at $400^{\circ}-300^{\circ} \mathrm{C}$. by moans of X-rays. Dr. J. L. Haughton directed the attention of the audience to the value of other physical measurernents such as electrical conductivity and dilatation.

Dr. L. Frommer finds it necessary to investigate his specimens in the form of lumps, because he is trying to follow the industrial process of age-hardening in a complex aluminium alloy. The difficulty is to obtain a useful surface. For this purpose he uses diamond turning and faces up the surface with the diamond. This prevents the surface layer from being distorted as with polishing. Dr. A. H. Jay has used a special method for getting X-ray photographs without powdering. A high narrow slit is used, the specimen being rotated to give continuous lines.

Dr. W. Hume-Rothery then commented on a point raised by Prof. Owen, who showed that the X-ray method follows the solubility curve better than the microscope at lower temperatures, and explained that it only needs more care to improve the microscopic results without waste of time. In answer to a request from Dr. Hume-Rothery for an explanation of intensity methods for determining phase diagrams by X-rays, Dr. A. J. Bradley remarked that the method has been mainly used for the determination of three-phase triangles in ternary systems. It needs three alloys in each triangle to give the approximate compositions of the corners from the relative proportions of the phases present in each alloy. More exact values can be obtained by making a new alloy near each corner. Much less than 1 per cent of the face-centred cubic or bodycentred cubic phases can be detected, but it is some. times difficult to detect the presence of phases with more complex structures. A very large camera would be needed if the structure was of low symmetry. Time is saved when the system contains many triangles.

Mr. C. Wainwright stressed the importance of expert chemical analysis. Mr. N. J. Petch pointed out that there is a vital difference in the behaviour of lumps and powder from low-alloy steels. Often when the lump remains austenitic, quenched filings may contain a great deal of martensite. Dr. A. H. Jay, in agreement with a previous speaker, recommended the electrolytic method of preparing surfaces instead of acid etching, which is not reliable.

Dr. H. Lipson would like to study the liquid state by means of X-rays, but considers that the microscopic method should be left to the metallurgists, while Dr. M. L. V. Gayler pleaded for co-operation between physicists and metallurgists. Emphasis was placed on the difference in behaviour between pure and commercial metals. Prof. E. A. Owen was also in favour of co-operation, and strongly supported the focusing camera.

Dr. W. A. Alexander pointed out some discrepancies between $\mathrm{X}$-ray and microscope results on the nickel-aluminium system. In the copper-nickelaluminium system there is a decrease in solid solubility as the alloy cools, which is important from the point of view of the hardening of copper-rich alloys. There is supersaturation at low temperatures. Dr. A. J. Bradley suggested three stages in precipitation at low temperatures: the first affects the physical properties, the second the X-ray results and the third the microscope results.

Mr. F. A. Fox urged that the X-ray worker should use the microscope, and Dr. L. Frommer stated that quenched lumps differ from the surface to the interior.

\section{ELECTRICAL ENGINEERS AND THE POST-WAR PERIOD}

T $\mathrm{N}$ his inaugural address on October 1 to the Institu1 tion of Electrical Engineers, Prof. C. L. Fortescue first referred to two aspects of the political and economic conditions likely to prevail in Great Britain after the War. First, a great effort will be made to improve the living and working conditions of the less highly paid members of the community; and secondly, Great Britain will for a long time import a large proportion of essential food supplies and a considerable quantity of the raw materials required for industries.

In discussing the export and import tendencies and in proposing a course of action to redress the balance, Prof. Fortescue considers that one of the first problems to be coped with in the post-war period is the conservation of coal and its more efficient use. In this connexion reference is made to the Weir Committee's report of 1931 on main-line electrification and to the Moore-Brabazon Committee's report of 1933 on the Severn barrage scheme, the provisions of which would save 9-10 million tons of coal a year in the one case and about $1 \frac{1}{2}$ million tons in the other. The Caledonian power and the Grampian (Glen Affric) power schemes are also mentioned. 
In the domestic sphere an improvement in the efficiency of heating apparatus might play a greater part in the conservation of coal than would the development of the rather scanty sources of available water-power. The possibility of using the energy of the condensate from power stations offers good prospects when planned in combination with intensive horticulture on a large scale and industries requiring considerable quantities of process steam.

Prof. Fortescue outlined the facilities and training which in his view should be made available to young men entering upon engineering careers in the postwar years. The school-leaving age will probably be raised to 15 or 16 , and four or five years will be needed after that for training in the sciences and for workshop instruction. A further two or three years should be devoted to subject-matter chosen from engineering practice, mathematics applied to engineering problems, industrial economics, works administration or industrial psychology. 'The student's final award would depend on the work done during the first four or five years and on the presentation of a satisfactory thesis covering the work of the later years; at the conclusion of this, the student should be ready to take his place in productive industry.

Prof. Fortescue makes a plea for the thorough investigation by engineers of the relative advantages of road and rail transport in Great Britain and also in such other spheres as the public health services and agriculture. The necessary researches would need to be conducted on a national scale, possibly by a national research institution or perhaps an extended Department of Scientific and Industrial Research.

Then there will be the urgent and difficult problem of reabsorbing men into industry from the Armed Forces without dislocating the lives of those who have remained in industry. Tentatively it is suggested that all the younger men in industry be gradually drafted into the Forces, after the War, for two or three years of military duty, their places being taken by men of suitable qualifications now in the Forces. By the time the young men from industry have completed these military duties, industry should be in a position gradually to re-absorb them.

Another problem of the immediate post-war period is that of ensuring that all large schemes of industrial replanning are given adequate consideration by our most capable and far-seeing men; during the first few years after the War reconstruction should be limited to that urgently required for those who are without homes as a result of the War.

\section{FORTHCOMING EVENTS}

(Meeting marked with an asterisk is open to the public)

Saturday, October 17

NuTritTon Soctery (at the London School of Hygiene and Tropical Medicine, Keppel Street, London, W.C.1), at 11 a.m. and 2.15 p.m.Conference on "Trace Elements in relation to Health".

Sunday, October 18

Association of ScIentific Workers (SOtTh WaLes AREa) (at the Royal Hotel, Cardiff), at 10 a.m.-Conference on "Science for Monday, October 19

Tercentenary OF THE INVEntion BY BLaISE Pascal OF THE CALCUlating Machine (at the Connaught Rooms, Great Queen Street, London, W.C.2), at 12.30 p.m.: Luncheon; at 3 p.m. to 6 p.m. : Ex-
hibition of Calculating Machines.

Friday, October 23

INSTITUTION OF MECHANICAC ENGINEERS (at Storey's Gate, St. James's Park, London, S.W.1), at 5.30 p.m.- Presidential Address by Colonel S. J. Thompson: "Boilers-Past and Present".

\section{APPOINTMENTS VACANT}

APPLIOATIONS are invited for the following appointments on or before the dates mentioned:

TEACHER OF. ENGINEERING DRA WING AND SCIENCE at the Castleford Whitwood Technical College and Junior Technical School-M. G Swaine, Education Offices, Smawthorne Lane, Castleford, Yorks. (October 20).

Research Assistant (graduate in Science or Agriculture)The Secretary, National Institute for Research in Dairying, Shinfleld, The Secretary, National

TeAdHer OF GENERAL SOLENCE SUBJECTS in the Junior Technical Department of the Mining and Technical College-The Principal, Technical College, Church Street, Barnsley (October 23).

Smcond Technical Assistant (MALE)-The Secretary, west of Scotland Agricultural College, 6 Blythswood Square, Glasgow (October 24).

Clinic Psyohologist (Woman) at the St. Andrews and Dunder Training Centre-The Director of Studies, Training College, Park Place, Dundee (October 24).

Lecturer (Man or woman) in Mathematios and Physios-The Principal and Clerk to the Governing Body, Wigan and District Mining and Technical College, Wigan (October 31 ).

LECTURER IN ENGINEERING SUBJECTS at the Medway Technical College, Senior Departments, Gillingham,-The District Education Officer, Fort Pitt House, Rochester.

\section{REPORTS and other PUBLICATIONS}

(not included in the monthly Books Supplement) Great Britain and Ireland

Bibliography on Wclding in Aircraft Construetion. (B.7.) Pp. 10 London : Institute Industrial Practice for Spot Welding Light Alloys. Prepared for the R.52 Sub-Committee on the Spot Welding of Light Alloys by a Panel R.521 on Technique for Spot Welding of Light Alloys. (T.8.) Pp. 12. (London: Institute of Welding.) [229 British Council Map No. 1: Europe and the Middle East. Scale $1: 11,000,000$. 30 in. $\times 24$ in. Printed in six colours. No. $2:$ The Far East. Scale 1:11,000,000. Outline edition. $30 \mathrm{in} \times 243 \mathrm{in}$. No. $3:$ North America to Britain. Scale $1: 11,000,000$. Outline edition.
30 in. $\times 24$ in. (London: Royal Geographical Society.) No. 1, tlat or folded in cover, 5 s.; No. 1 , flat, with Nos. 2 and 3 in Outline, $8 s$.

\section{Other Countries}

Indian Ecological Society. First Annual Report. Pp. 6. (Bombay Royal Institute of Science.)

Report of the King Institute of Preventive Medicine, Guindy, by Major K. Padmanabha Menon, and Report of the Government Analyst Madras, by Herbert Hawley. Pp. ii +72. (Madras: Government
[229

Records of the Geological Survey of India. Vol. 76 (Bulletins of Economic Minerals, No, 6): Indian Precious Stones. By L. A. N. Iyer. Pp. $54+2$ plates. (Calcutta: Geological Survey of India.) Forest Research Institute, Dehra Dun. Indian Forest Leaflet No.
19: A Substitute Wax for Carnauba. By S. V. Puntambekar. Pp. 19: A Substitute Wax for Carnauba. By S. V. Puntambekar. Pp.
iif 4. (Dehra Dun : Forest Research Institute.) 4 annas ; $6 d$. Indian Forest Records, New Series. Silviculture, Vol. 4, No. 5 Stump Production in Madras Teak Nurseries. By A. I. Griffith. Pp. iv $+225-257+3$ plates. (Delhi : Manager of Publications.) 1.8 rupees
$2 s .3 d$.
[229 Carl Wilhelm Scheele. Manuskript 1756-1777. Ordnade av C. W. oseen. Ljustryck. Pp. v+182. Manuskript 1756-1777. Tolkning av O. W. Oseen. Pp. vi +173 . (Stockholm: K. Svenska Vetenskaps(Tomien.) of Trayancore. Administration Report of the Govern ment Museum, 1116 M.E. Pp. il+10. (Trivandrum: Government Press.)

Proceedings of the California Academy of Sciences, Fourth Series. Vol. 23, No. 31: Notes on a Collection of Reptiles and Amphibians from Guatemala, 2: Lizards. By Joseph R. Slevin. Pp. 453 -462 Vol. 23, No. 32: Notes on a Collection of Reptiles from Boquete Panama, with the Description of a New Species of Hydromorphous. By Joseph R. Slevin. Pp. 463-480 + plates 39-42. Vol. 23, No. 33 Redescription of Three Species of the Polychaetous Family Polynoidae from California. By Tage Skogsberg. Pp. 481-502 +plate 43. Vol. 24 No. 1: Contributions toward a Knowledge of the Insect Fauna of Lower California, No. 1: Introductory Account. By A. E. Michelbacher and E. S. Ross. Pp. 20 t plates 1-3. Vol. 24, No. 2 : Contributions toward a Knowledge of the Insect Fauna of Lower California. No. 2: Coleoptera: Cerambycidae. By F. Gorton Linsley. Pp 21-96 + plates 4-5. Vol. 24, No. 3: Contributions toward a Know ledge of the Insect Fauna of Lower California, No. 3: Coleoptera Buprestidae. By Prof. Edwin C. Van Dyke. Pp. 97-132 + plates 6-7. Vol. 24, No. 4: Contributions toward a Knowledge of the Insect Fauna of Lower California, No. 4: Neuroptera: Myrmeleonidae. By Nathan Banks. Pp. 133-152+ plate 8. Vol, 24, No. 5 : Contributions toward a Knowledge of the Insect Fauna of Lower California, No. 5: Symphyla. By A. E. Michelbacher. Pp. 153-160+plate 9 . Voi. 24, No. 6: Contributions toward a Knowledge of the Insect Fauna of Lower California. No. 6: Diptera : Culicidae. By Thomas H. G. Aitken. Pp. 161-170. (San Franctsco: California Academy of
[2iences.) 